If you would like more information on this award or would like to submit an application please visit the AATS Web site at www.aats.org

\section{AATS Cardiothoracic Surgery Resident Poster Competition}

Now accepting commitments-January 15, 2015, Deadline

The AATS Resident Poster Competition provides an opportunity for a senior cardiothoracic surgery resident and/or congenital heart surgery fellow to represent their institution in a competition by presenting a scientific poster of their clinical/investigative research at the 2015 AATS Annual Meeting in Seattle, Washington, April 25-29.

To be eligible for the program, North American residents must be the most senior resident enrolled in either an ACGME-accredited or RCPSC-accredited cardiothoracic surgery residency program or congenital heart surgery fellowship. International residents must be in their last year of a cardiothoracic training program at an AATS Member's institution.

Funded by the AATS Graham Foundation, participating residents will receive a stipend of $\$ 500$ to help offset the cost of travel and hotel accommodations at the Annual Meeting. Additionally, the Foundation will provide every participant with complimentary registration which will include one Postgraduate course, and one Skills course.

For more information or to submit a resident for participation please visit the AATS Web site at www.aats.org or contact the AATS administrative office via E-mail at admin@aats.org.

\section{AATS Grant Writing Workshop}

March 27, 2015, Bethesda, MD

Organized by the AATS Scientific Affairs and Government Relations Committee, the 2015 AATS Grant Writing Workshop will take place on Friday, March 27, 2015, at the Doubletree Bethesda in Bethesda, MD (9 miles from Washington, DC). This full-day program is designed for all levels of academic cardiothoracic surgeons interested in applying for grants.

The workshop will provide attendees with a better understanding of the complex nature of preparing and submitting grant proposals along with the techniques required to ensure submissions are of the highest quality. Through a didactic session, interactive panel discussions and a mock study session, attendees will work with well-known leaders in cardiothoracic surgery and NIH Staff to achieve the following:

- Create career development and training grants

- Analyze outcomes research and clinical research networks

- Assess the structure and components of a grant

- Identify extramural program and funding opportunitiesNCI and NHLBI

- Understand the steps to becoming an NIH investigator

The deadline for registration is Friday, March 13, 2013. For additional information on the workshop program, housing, and to register, please visit www.aats. org.

\section{AATS Graham Foundation F. Griffith Pearson Fellowship}

Deadline: January 31, 2015

Provides an educational experience for North American general thoracic surgeons to spend a focused period of four to six weeks studying clinical techniques at a North American host institution of their choice. The fellowship is funded and administered by the AATS Graham Foundation and provides a grant of $\$ 3,500$ to three successful applicants to defray the cost of their living expenses during their training. Additionally, recipients will receive complimentary scientific registration to the 95th AATS Annual Meeting April 25-29, 2015, in Seattle, Washington.

\section{Fellowship Eligibility:}

- A candidate should have completed his/her formal training in general surgery and in thoracic surgery prior to the start of the fellowship, with general thoracic surgery as their primary specialty.

- Candidates must have an academic or hospital appointment.

- Candidates must be in their first 3 years post-thoracic training.

- Candidates are strongly suggested to attend the AATS Annual Meeting to receive their recognition plaque from Dr F. Griffith Pearson.

For more information on the F. Griffith Pearson Fellowship or to submit an application, please visit the Foundation's Web site at www.aatsgrahamfoundation.org. 